University of Nebraska - Lincoln

DigitalCommons@University of Nebraska - Lincoln

Agronomy \& Horticulture -- Faculty Publications

Agronomy and Horticulture Department

2012

\title{
Effectiveness of Grass Filters in Reducing Phosphorus and Sediment Runoff
}

\author{
Ahmed Al-wadaey \\ International Center for Agricultural Research in Dry Areas (ICARDA), Aleppo, Syria, \\ aalwadaey@gmail.com \\ Charles S. Wortmann \\ University of Nebraska-Lincoln, cwortmann2@unl.edu \\ Thomas G. Franti \\ University of Nebraska-Lincoln, thomas.franti@unl.edu \\ Charles A. Shapiro \\ University of Nebraska-Lincoln, cshapiro1@unl.edu \\ Dean E. Eisenhauer \\ University of Nebraska-Lincoln, deisenhauer1@unl.edu
}

Follow this and additional works at: https://digitalcommons.unl.edu/agronomyfacpub

Part of the Agriculture Commons, Agronomy and Crop Sciences Commons, Environmental Indicators and Impact Assessment Commons, Horticulture Commons, Natural Resources and Conservation Commons, Sustainability Commons, and the Water Resource Management Commons

Al-wadaey, Ahmed; Wortmann, Charles S.; Franti, Thomas G.; Shapiro, Charles A.; and Eisenhauer, Dean E., "Effectiveness of Grass Filters in Reducing Phosphorus and Sediment Runoff" (2012). Agronomy \& Horticulture -- Faculty Publications. 725.

https://digitalcommons.unl.edu/agronomyfacpub/725

This Article is brought to you for free and open access by the Agronomy and Horticulture Department at DigitalCommons@University of Nebraska - Lincoln. It has been accepted for inclusion in Agronomy \& Horticulture -Faculty Publications by an authorized administrator of DigitalCommons@University of Nebraska - Lincoln. 
Published in Water, Air, \& Soil Pollution, An International Journal of Environmental Pollution 223 (2012), pp. 5865-5875; doi: 10.1007/s11270-012-1322-2

Copyright (C) 2012 Springer Science+Business Media B.V. Used by permission.

Submitted February 26, 2012; accepted September 6, 2012; published online October 7, 2012.

\title{
Effectiveness of Grass Filters in Reducing Phosphorus and Sediment Runoff
}

\author{
Ahmed Al-wadaey, ${ }^{1}$ Charles S. Wortmann, ${ }^{2}$ Thomas G. Franti, ${ }^{3}$ \\ Charles A. Shapiro ${ }^{4}$ and Dean E. Eisenhauer ${ }^{3}$
}

1. International Center for Agricultural Research in Dry Areas (ICARDA),

P. O. Box 5466, Aleppo, Syrian Arab Republic,

2. Department of Agronomy and Horticulture, University of Nebraska-Lincoln, Lincoln, NE, USA

3. Department of Biological Systems Engineering, University of Nebraska-Lincoln, Lincoln, NE, USA

4. Department of Agronomy and Horticulture and Haskell Agricultural Laboratory, University of Nebraska-Lincoln, Lincoln \& Concord, NE, USA

Corresponding author - Ahmed Al-wadaey, email aalwadaey@gmail.com, Emails: Ahmed Al-wadaey, A.AL-Wadaey@cgiar.org; Charles S. Wortmann, cwortmann2@unl.edu; Thomas G. Franti, thranti@unl.edu; Charles A. Shapiro, cshapiro1@unl.edu, Dean E. Eisenhauer, deisenhauer1@unl.edu

\begin{abstract}
Surface water contamination can often be reduced by passing runoff water through perennial grass filters. Research was conducted in 2006 to 2008 to evaluate the size of cool season grass filters consisting primarily of tall fescue (Festuca arundinacea Schreb) with some orchard grass (Dactylis glomerata L.) relative to drainage area size in reducing runoff sediment and phosphorus (P). The soil was Pohocco silt loam Typic Eutrochrepts with a median slope of $5.5 \%$. The grass filters occupying 1.1 and $4.3 \%$ of the plot area were compared with no filter with four replications. The filters were planted in the $\mathrm{V}$ shaped plot outlets which were $3.7 \times 11.0 \mathrm{~m}$ in size. The filter effect on sediment and $\mathrm{P}$ concentration was determined from four natural runoff events when nearly all plots had runoff. Filter effect on runoff volume and contaminant load was determined using total runoff and composites of samples collected from 12 runoff events. Sediment concentration was reduced by $25 \%$ with filters compared with no filter (from 1.10 to $1.47 \mathrm{~g} \mathrm{~L}^{-1}$ ), but $\mathrm{P}$ concentration was not affected. The 1.1
\end{abstract}

and $4.3 \%$ filters, respectively, compared with having no grass filter, reduced: runoff volume by 54 and $79 \%$; sediment load by 67 and $84 \%$ (357 to $58 \mathrm{kgha}^{-1}$ ); total P load by 68 and $76 \%$ ( 0.58 to $0.14 \mathrm{~kg} \mathrm{ha}^{-1}$ ); particulate $\mathrm{P}$ (PP) load by 66 and $82 \%$ ( 0.39 to $\left.0.07 \mathrm{~kg} \mathrm{ha}^{-1}\right)$; and dissolved reactive $\mathrm{P}$ (DRP) load by 73 and $66 \%$ (0.2 to $\left.0.07 \mathrm{kgha}^{-1}\right)$, respectfully. A snowmelt runoff event had $56 \%$ greater DRP concentration compared with rainfall-induced runoff events. Grass filters reduced sediment and $\mathrm{P}$ load largely by reducing runoff volume rather than reducing concentration. Well-designed and well-placed grass filters that occupy 1.0 to $1.5 \%$ of the drainage area and intercept a uniform flow of runoff from a drainage area can reduce sediment and nutrient loss in runoff by greater than $50 \%$.

Keywords: Sediment, grass filter, tall fescue, water quality

An erratum to this article can be found at http://link.springer.com/article/10.1007\%2Fs11270-013-1661-7

That correction (to a Reference citation) has been incorporated. 


\section{Introduction}

Contamination of surface waters with sediment and nutrients carried in runoff from agricultural fields degrade water quality which can result in a critical environmental impact. Agricultural land has been identified as the leading source of $\mathrm{N}$, phosphorus $(\mathrm{P})$, and sediment loading to surface waters, contributing to eutrophication that affects nearly $50 \%$ of the lakes and reservoirs in the United States (USEPA 2003; Gitau et al. 2005). This pollutant loading is associated with runoff and soil erosion (Culley and Bolton 1983).

Vegetative filter strips, riparian buffers, and grass filters placed to intercept runoff from a field can be used to reduce water pollution from agricultural runoff. Grass filters remove sediment and both sediment bound and dissolved nutrients from surface runoff by increasing deposition through adsorption of sediment and nutrients, reduced runoff velocity, and increased infiltration (Daniels and Gilliam 1996; Schmitt et al. 1999; Abu-Zreig et al. 2003; Dorioz et al. 2006). Filters remove primarily larger sediment particles of sand and silt, while clay particles may be only partially removed depending on the strip width and water flow rate (USDA-NRCS 2002; Nighman and Harbor 1997). Runoff reduction due to infiltration while passing through a filter strip can account for much of the reduction in sediment and soluble nutrients reaching surface waters (Dosskey et al. 2007). Blanco-Canqui et al. (2004) found $53 \%$ of soluble N and $\mathrm{P}$ to be removed from runoff with $0.7-\mathrm{m}$-wide fescue filter strips, mainly because of increased infiltration and adsorption to organic matter and clay. Clausen et al. (2000) found that grass filter strips reduced nitrate concentration in leachate by $35 \%$ and $\mathrm{N}$ and $\mathrm{P}$ concentration in runoff by $>70 \%$. Dillaha et al. (1989) reported that filtration is more significant for the larger soil particles, aggregates, and manure particles, while adsorption is probably more significant with respect to the removal of soluble pollutants. Dosskey et al. (2002) estimated that riparian buffers on four different farms could remove 41 to $99 \%$ of the sediment from field runoff if the runoff is uniformly distributed over the entire buffer area. However, this performance will vary depending on conditions of the buffer and flow through the buffer, and the trapping may be reduced when flow is not uniformly distributed (Helmers et al. 2008).

The effectiveness of grass filters is related to incoming sediment and nutrient load, flow rate, grass height and density, and strip width (Dillaha et al. 1986), as well as degree of submergence (Wilson 1967). Using the process-based VFSMOD model, Dosskey et al. (2008) found that slope and soil texture were the most important site factors in determining filter strip width. Grass filter strip effectiveness is reduced when runoff inundates the filters as often occurs where flow is concentrated (Blanco-Canqui et al. 2004; Dosskey et al. 2002). Topography and microrelief of fields and riparian zones often prevent uniform distribution of runoff across filters and buffer areas.

Schmitt et al. (1999) compared 7.5- and 15-m filter strip (mixed grass-shrub-tree) widths and found that doubling filter strip width doubled infiltration and dilution but did not increase sediment deposition. Moreover, Gharabaghi et al. (2002) found that the first $5 \mathrm{~m}$ of the grass filter strip width were critical for sediment removal with most particles $>40 \mu \mathrm{m}$ captured within the first few meters of the grass filter strip. However, Neibling and Alberts (1979) found $91 \%$ of incoming sediment was deposited in the first $0.6 \mathrm{~m}$ of the filter strip. Mankin et al. (2007) demonstrated that adequately designed and implemented grass-shrub riparian buffers with widths of only $8 \mathrm{~m}$ improved water quality, particularly with adequate infiltration which accounted for $>75 \%$ of the total soluble solids removal, $>90 \%$ of the total $\mathrm{P}$ removal, and $>90 \%$ of the total $\mathrm{N}$ removal.

Liu et al. (2008) developed a regression equation between sediment removal and the two variables of slope and buffer width and found that a 10-m width was near optimal for sediment trapping and that trapping efficiency was greater on a $9 \%$ slope compared with greater or lesser slopes, although the $\mathrm{R}^{2}$ values on their functions point to much unexplained variability. Previous studies by Fox and Sabbagh (2009) attempted to develop general statistical relationships between sediment and/or nutrients trapping as functions of buffer physical characteristics such as width and slope, but due to a lack of consideration for hydrological processes, they cannot predict strong relationships between the variables. Gumiere et al. (2010), in review of numerous studies, found, however, that filter area slope and width, at least not wider than $4 \mathrm{~m}$, were not related to sediment removal, agreeing 
that to the finding of Neibling and Alberts (1979) that most incoming sediment was deposited in the first $0.6 \mathrm{~m}$ of the filter strip.

Much research has been conducted on composition and width of riparian buffers and filter strips. However, size of grass filters, designed and placed to intercept uniform runoff flows from a field, relative to drainage area size has been less investigated (Helmers et al. 2002). Buffers and filter strips commonly occupy a significant part, ranging from 2 to $67 \%$, of the drainage area in studies reviewed by Liu et al. (2008). There is a large information gap concerning the size of wellplaced filter areas relative to the drainage area.

There is a need for additional plot scale studies on grass filter. This is because of the variation of the magnitude of trapping efficiency for a given buffer area ratio with site conditions such as slope, soil texture, and field practices that also determine the magnitude of the runoff load from a field and the trapping capability of a grass filter. Watershed planners often express desired levels of impact in terms of a percentage reduction of runoff and nutrient load that is required to meet some regulatory limit; thus, a useful quantitative design model, based on such runoff plot studies, would identify the buffer area ratio of filter strip that achieves that percentage. The objective of this research was to determine the effect of size of perennial cool-season grass filter areas relative to the drainage area size in reducing runoff volume as well as the concentration and loading of sediment and $\mathrm{P}$ from a test high soil $\mathrm{P}$ with field under natural precipitation conditions.

\section{Materials and Methods}

\subsection{Study Site and Experimental Design}

The effectiveness of grass filters in reducing $\mathrm{P}$ and sediment loading to surface waters was evaluated at the University of Nebraska Agricultural Research

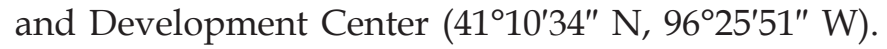
The elevation above sea level was $345 \mathrm{~m}$ (1,132 ft). The runoff facility was established in 1998 on an irrigated Pohocco silt loam derived from upland loess (fine-silty, mixed, mesic Typic Eutrochrepts; texture $280 \mathrm{~g} \mathrm{~kg}^{-1}$ sand, $580 \mathrm{~g} \mathrm{~kg}^{-1}$ silt, and $140 \mathrm{~g} \mathrm{~kg}^{-1}$ clay). The soil Bray-1 P is 180 ppm, SOM is $3.2 \%$, and soil $\mathrm{pH}$ is 6.9 .
The runoff plot dimension was $3.7 \mathrm{~m} \times 11.0 \mathrm{~m}$ plus a $\mathrm{V}$-shaped downslope end to direct flow to an outlet pipe for runoff and sediment collection. The slope for individual plots ranged from 4 to $7 \%$, with a median slope of $5.5 \%$. Each plot was enclosed with a 15-cm-wide metal barrier set approximately $7 \mathrm{~cm}$ into the ground to prevent entry or loss of runoff. Runoff was channeled to a 5-cm pipe and conveyed to a 450-L tank. A 22-L bucket was placed within the tank at the outlet to accommodate accurate measurement of small runoff events (Figure 1). A second 450-L tank was connected via an overflow tube to the first tank to accommodate very large runoff events. The tanks were calibrated to relate depth of measurement to volume.

Grass filters were established in the V-shaped outlet part of the plots (Figure 5) and occupied 0,1.1, and $4.3 \%$ of the drainage area. The grass filters were established by transplanting sod from the surrounding field that was composed of a 70:30 mixture of tall fescue and orchard grass in March 2006. Grass establishment was by transplanting rather than sowing to achieve earlier establishment of effective grass filters (Figure 2). Overall, cover of the V-shaped area with grass filter was reasonably uniform by the time the experiment was conducted (Figure 3). Regular maintenance was done to ensure growth of grass and there is no artificial lip between the sod and field. No corn or soybean was planted in the grass area. There were four replications.

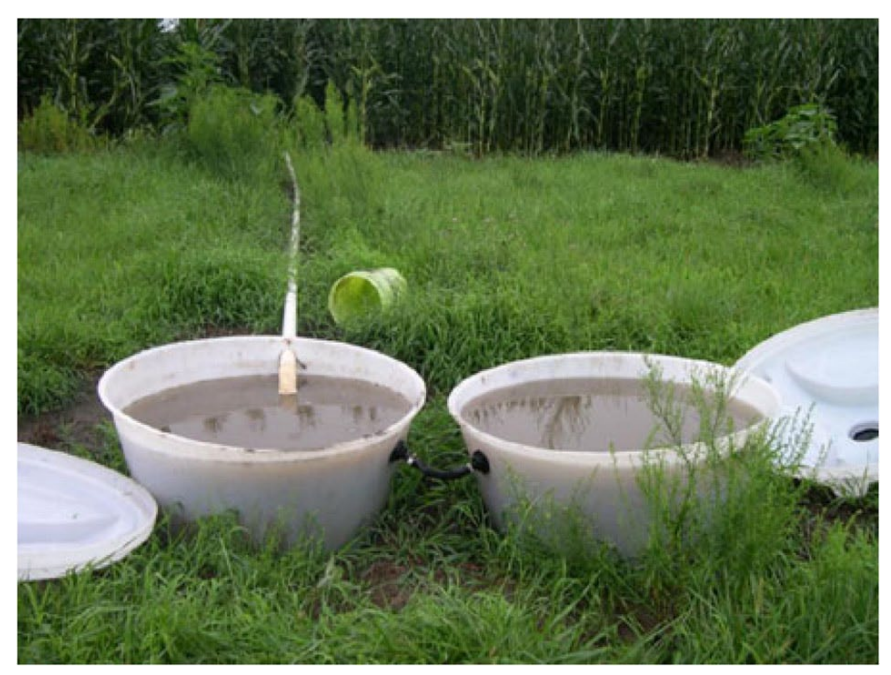

Figure 1. Runoff tanks for collecting water samples after each runoff event 
Figure 2. Planting fescue grass at runoff plots.

a) V-shaped area of grass $1.5 \mathrm{~m}$ wide before planting.

b) V-shaped area after transplanting Fescue grass.

c) Fescue grass $0.75 \mathrm{~m}$ in the first year of 2006 .

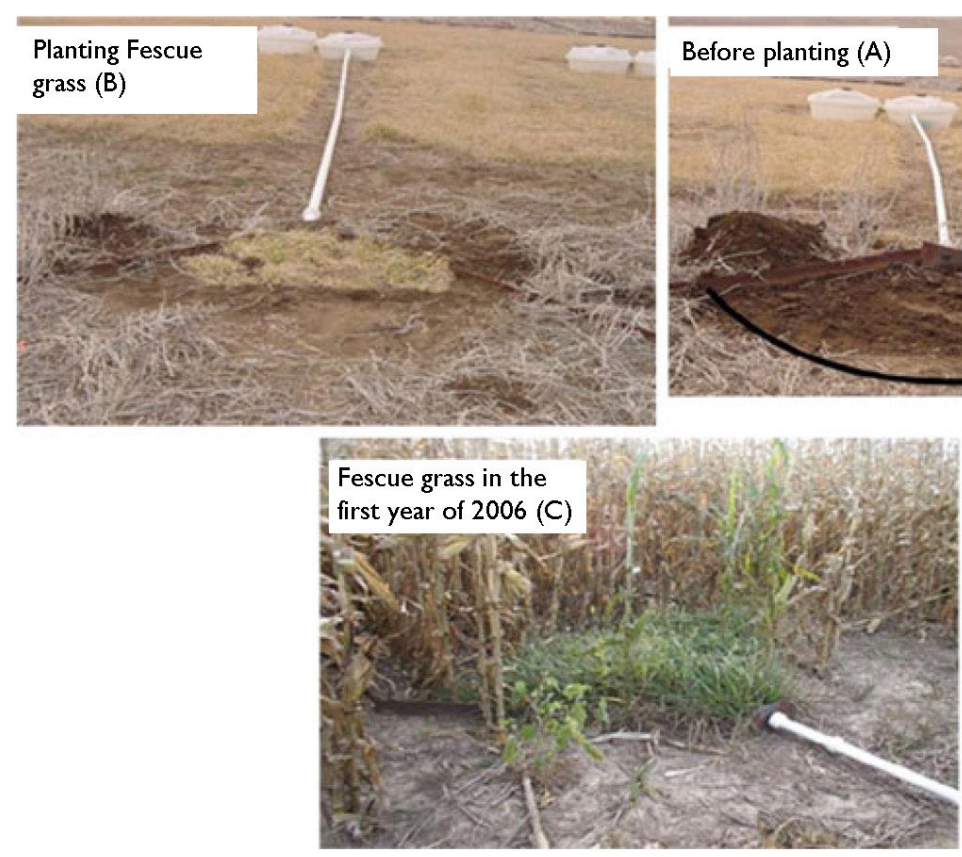

Tillage for all plots consisted of preplant disk tillage. Soil bulk density was $1.12 \mathrm{Mg} \mathrm{m}^{-3}$ at $0-5 \mathrm{~cm}$ depth and soil porosity was $58 \%$. Corn (Zea mays

Figure 3. Experimental plot diagram showing the V-shaped of grass filter area and connected pipe that direct runoff from plot to runoff tanks.
L.) and soybean [Glycine $\max$ (L.) Merr.] were planted in 0.76-m rows in 2006 and 2007, respectively. Fertilizer $\mathrm{N}\left(\mathrm{NH}_{4} \mathrm{NO}_{3}\right)$ was applied to all

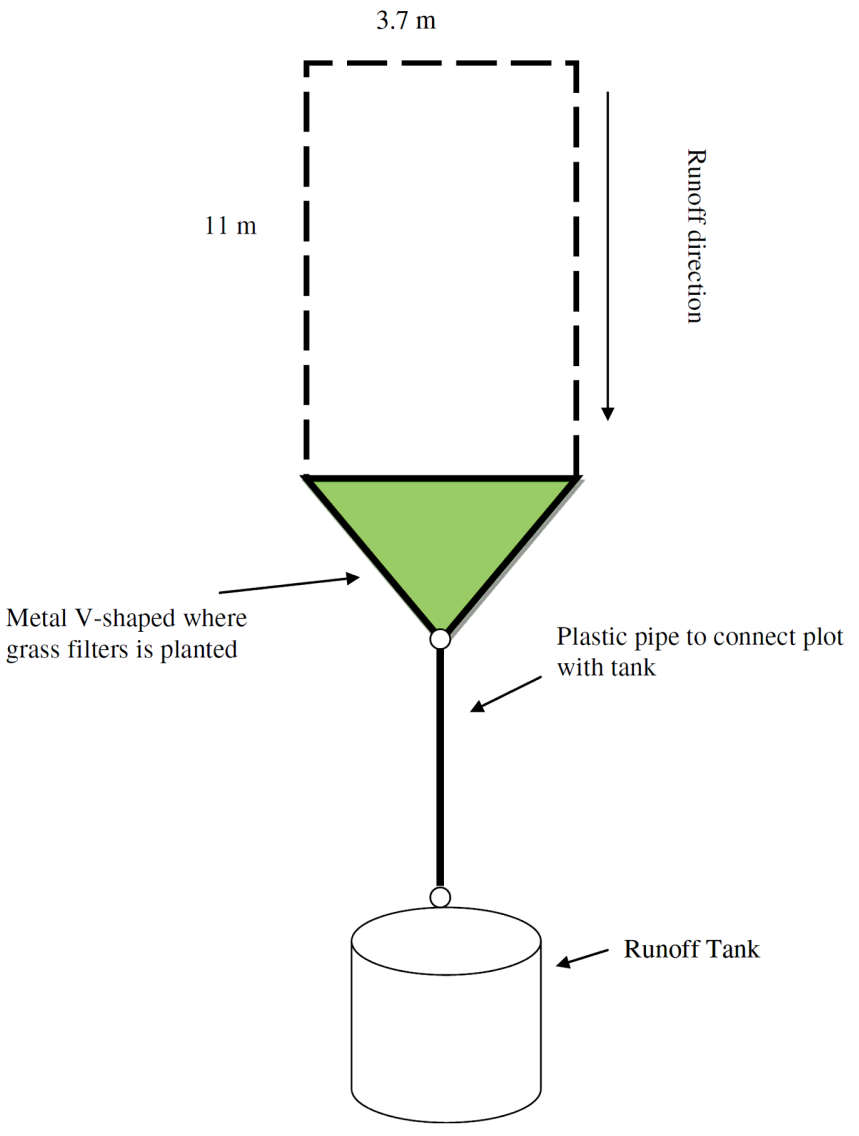


plots in 2006 at $73 \mathrm{~kg} \mathrm{Nha}^{-1}$. Corn and soybean varieties were glyphosate [N-(phosphonomethyl) glycine]-tolerant and weeds were controlled with application of glyphosate as needed. The site was irrigated with a center pivot. Irrigation did not cause runoff directly but may have contributed to some runoff events because of higher soil water content and slower infiltration compared with nonirrigated conditions. The precipitation was $700 \mathrm{~mm}$ plus $346 \mathrm{~mm}$ applied in irrigation in 2006 and $803 \mathrm{~mm}$ plus $215 \mathrm{~mm}$ applied in irrigation in 2007 (Figure 4). All runoff events occurred from March through August and were associated with rainfall or snowmelt.

\subsection{Runoff Sample Collection and Analysis}

Runoff volume was calculated from the measured depth of collected runoff in the tank using calibrated equations. A 1-L sample was taken after thorough stirring of the runoff and sediment in the tank and stored at $4{ }^{\circ} \mathrm{C}$ until sediment and $\mathrm{P}$ analyses were performed. Runoff samples were collected from 12 runoff events (Table 1). Composites of all samples weighted according to plot runoff volume for each event were formed for 2006 and 2007 and analyzed for sediment and $\mathrm{P}$ concentration. A volume of $250 \mathrm{~mL}$ of composite samples was calculated as follows:

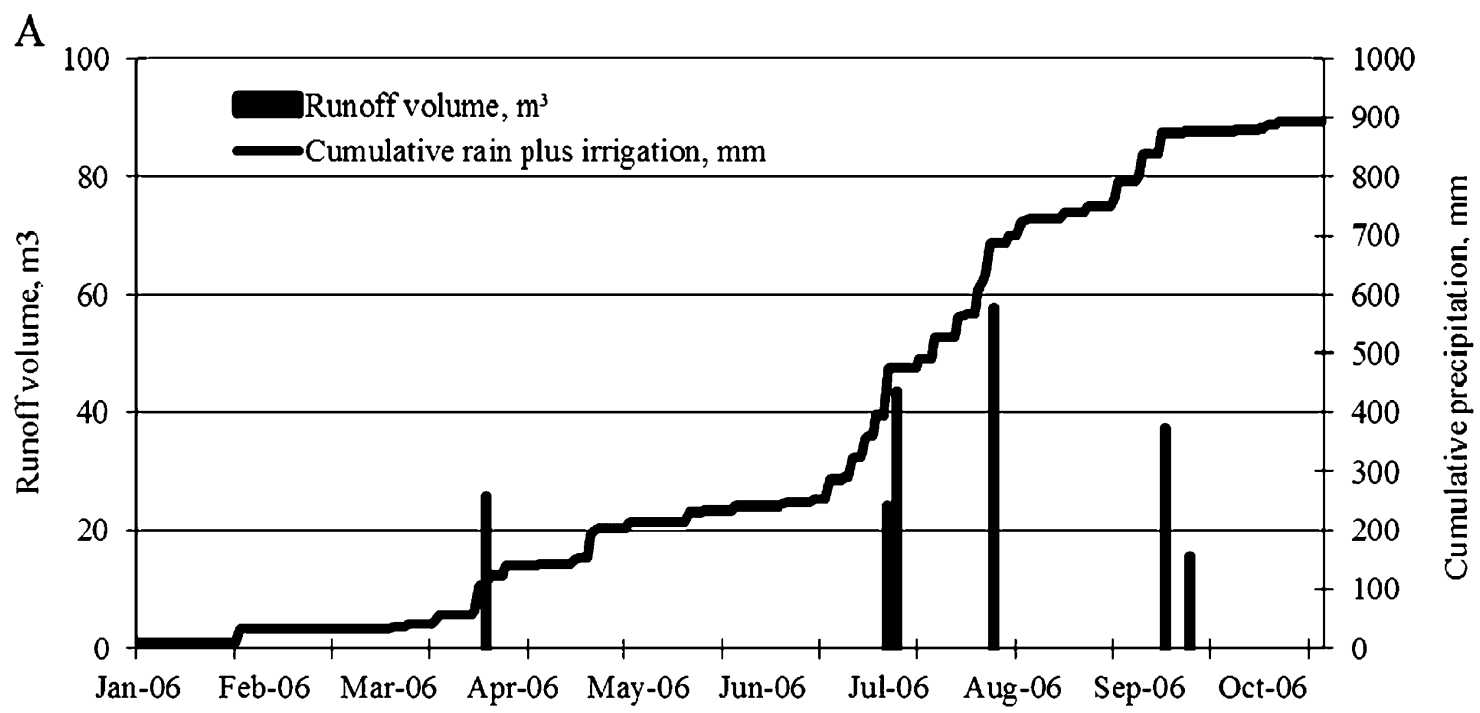

B

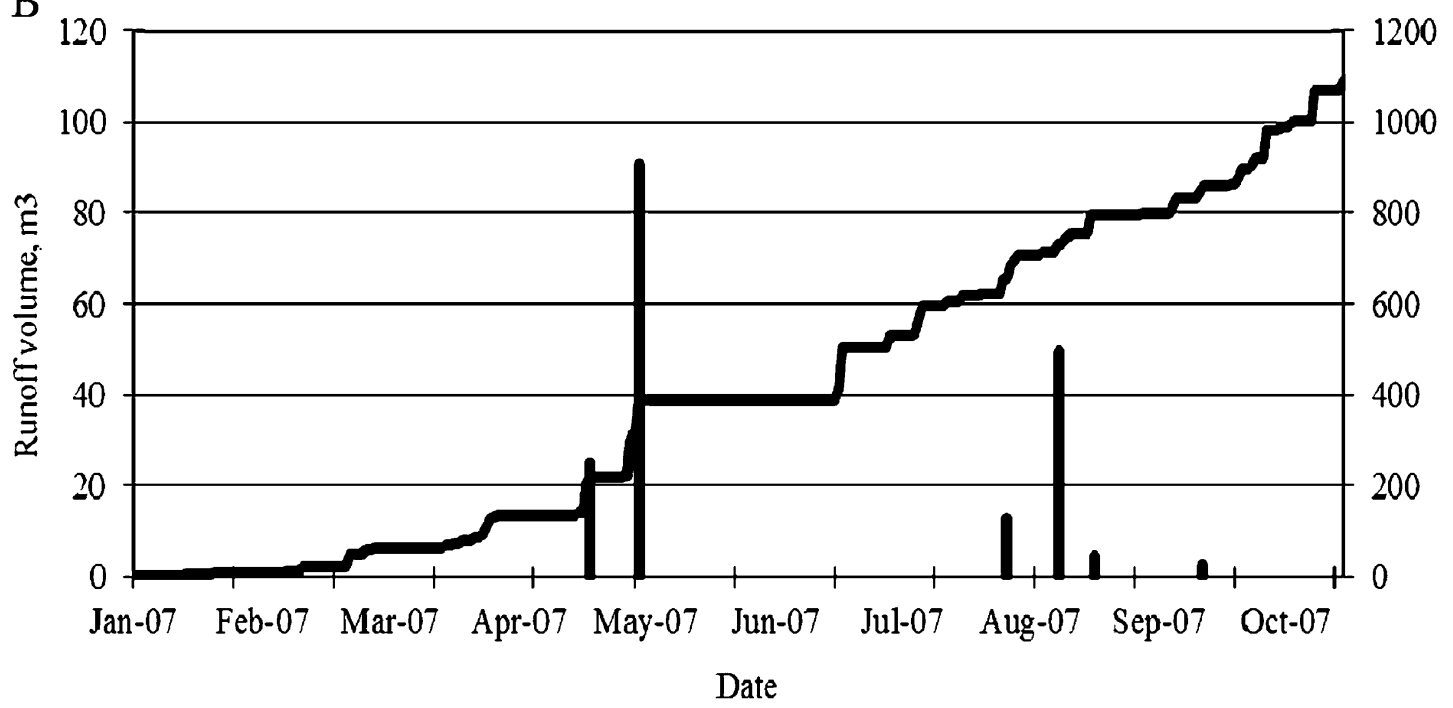

Figure 4. Cumulative rainfall and irrigation and runoff volume for a) 2006, and b) 2007 events. 
Composite sample $=$

$$
\sum\left(\frac{\text { Runoff volume in each event }}{\text { Total runoff volume from all events }}\right) \times 250
$$

Sediment and P load were calculated by multiplying runoff volume by concentration. In addition, runoff samples for four events in which most plots had runoff were analyzed separately to determine filter effect on contaminant concentration.

Sediment concentration was gravimetrically determined by drying $10 \mathrm{~mL}$ of unfiltered runoff sample at $104{ }^{\circ} \mathrm{C}$. Total $\mathrm{P}$ was determined on unfiltered runoff samples using the perchloric/nitric acid extraction $\left(\mathrm{HClO}_{4}-\mathrm{HNO}_{3}\right)$ digestion method (Olsen and Sommers 1982). Dissolved reactive P (DRP) in runoff was determined after filtration of a $100-\mathrm{mL}$ sample to $<0.45 \mu \mathrm{m}$ (Pote and Daniel 2000). The difference between total $\mathrm{P}$ and DRP was considered particulate $\mathrm{P}$ (PP), and dissolved unreactive $\mathrm{P}$ was included in this difference. All P fractions were measured colorimetrically at $880 \mathrm{~nm}$ with a Spectronic 601 spectrophotometer (Milton Roy, Rochester, NY, USA) according to Murphy and Riley (1962).

\subsection{Statistical Analysis}

Analyses of variance were conducted for runoff volume as well as P and sediment concentrations and loads using the PROC MIXED procedure for repeated measures (SAS Institute 2003). Treatments were fixed effects, and years, replications, and events were random effects. Treatment effects on runoff were considered significant at $\mathrm{P} \leq 0.1$. A combined ANOVA for two runoff events in 2006 and one in 2007 and a separate ANOVA for a snowmelt event in 2008 were conducted to determine treatment effects on contaminant concentration. The snowmelt event was analyzed separately as the ground was frozen and the filter grass was cut short $(10 \mathrm{~cm})$ in the previous fall. Snow event separation from runoff events in the statistical analysis is necessary to eliminate the impact of runoff sample analysis results on snowmelt samples, .i.e., the differences which can arise for $\mathrm{P}$ and sediment results between snowmelt and runoff samples. During snowmelt sampling, the ground is frozen, which will impact on amount of runoff, DRP due to infiltration, and slow movement of snowmelt compared with runoff events. Meanwhile, the grass was cut before winter and collection of snowmelts samples. In this case, grass performance will be different in the two situations. Therefore, including runoff events and snowmelt events in the same statistical model without separating their impact will result in biased output of $\mathrm{P}$ and sediment load and concentration. The PROC MIXED procedure was also used for the composite samples made up from the 12 runoff events of 2006 and 2007 to determine the filter effect on contaminant concentrations and loads.

Table 1. Characteristics of runoff events at the University of Nebraska Agricultural Research and Development Center, east central Nebraska at Mead

\begin{tabular}{lcccc}
\hline Date & Amount $(\mathrm{mm})$ & Peak intensity $\left(\mathrm{mmh}^{-1}\right)$ & Mean runoff volume ${ }^{\mathrm{a}}\left(\mathrm{m}^{3} \mathrm{ha}^{-1}\right)$ & Runoff depth $(\mathrm{mm})$ \\
\hline $3 / 31 / 2006$ & 41 & 41 & 25.8 & 5.07 \\
$7 / 12 / 2006$ & 89 & 30 & 24.2 & 4.11 \\
$7 / 14 / 2006$ & 41 & 31 & 43.7 & 5.94 \\
$8 / 8 / 2006$ & 140 & 25 & 57.6 & 9.61 \\
$9 / 21 / 2006$ & 48 & 15 & 37.4 & 6.93 \\
$9 / 27 / 2006$ & 43 & 17 & 15.7 & 2.72 \\
$4 / 25 / 2007$ & 104 & 11 & 25.2 & 5.11 \\
$5 / 7 / 2007$ & 109 & 18 & 90.6 & 12.48 \\
$8 / 7 / 2007$ & 58 & 26 & 12.9 & 3.25 \\
$8 / 20 / 2007$ & 61 & 28 & 49.5 & 6.21 \\
$8 / 29 / 2007$ & 32 & 24 & 4.6 & 0.73 \\
$9 / 25 / 2007$ & 38 & 20 & 2.6 & 0.40 \\
\hline
\end{tabular}

a. Standard error of the mean is 2.1 and sample standard deviation is 25.13 


\section{Results and Discussion}

Runoff events occurred during spring and summer months (Table 1). Runoff volume was related to the amount of rainfall but not to 1-h peak rainfall intensity. In Table 1, the rainfall intensity varies over the duration of rain events. The majority of the rain events were of light to moderate intensity ranging from 11 to $41 \mathrm{mmh}^{-1}$ (Table 1). Although the amount of rain can be high in some events as in $\mathrm{Au}-$ gust 8, $2006(140 \mathrm{~mm})$, the amount of generated runoff wasn't significant $\left(57.6 \mathrm{~m}^{3} \mathrm{ha}^{-1}\right)$ due to low rainfall intensity in addition to the effect of grass filters of reducing runoff velocity and increase infiltration. Petrovic (1990) and Erickson et al. (2001) reported that little runoff was generated from turf grass surfaces compared to other land covers under natural precipitation. Heavier rainfall usually translates into more impact on the soil surface resulting in larger amounts of sediment being dislodged and carried away with runoff water. In Table 1, the event occurred on March 312006 with an amount of only $41 \mathrm{~mm}$, resulting in about $26 \mathrm{~m}^{3} \mathrm{ha}^{-1}$ because the intensity was $41 \mathrm{~mm} \mathrm{~h}^{-1}$. However, on the April 25, 2007 event, the amount was $104 \mathrm{~mm}$ but the intensity was only $11 \mathrm{mmh}^{-1}$, which resulted in runoff volume of only $25 \mathrm{~m}^{3} \mathrm{ha}^{-1}$.

The volume of runoff, $\mathrm{P}$ concentration, and sediment loads were low compared to what might be expected in the field with longer slopes (Figure 4;
Table 2). Slope length affects runoff volume because longer slopes offer a greater surface area to collect precipitation, increasing potential runoff volume and nutrient movement. Also, increasing slope length allows the runoff velocity to increase. However, grass filters might reduce velocity and increase infiltration. In Table 2, runoff volume was significantly reduced by $64 \%$ with grass filters occupying $4.3 \%$ of the area (from $72.4 \mathrm{~m}^{3} \mathrm{ha}^{-1}$ to $26.2 \mathrm{~m}^{3} \mathrm{ha}^{-1}$ ) and only $39 \%$ (72.4 to $44 \mathrm{~m}^{3} \mathrm{ha}^{-1}$ ) with grass filters occupying $1.1 \%$ of the drainage area.

This is a constraint of runoff plot studies and the results need to be interpreted in terms of relative effects of treatments rather than absolute effects on runoff volume and pollutant load. Storm characteristics such as rainfall intensity and duration can impact the runoff generation. Studies of rainfall records show that actual storm distributions and durations can vary considerably from event to event. A rainfall may be evenly distributed over a time period or can vary widely within that same period. Its duration can also be long or very short. These different types of rain events can produce extremely different runoff volumes and peak discharges.

Limited comparisons of sediment and P loss dynamics from agricultural fields under snowmelt and rainfall runoff conditions exist despite significant differences in underlying particle detachment and transport processes during these two periods. The results

Table 2. Grass filter area, as percent of drainage area, effect on runoff volume as well as on sediment, and $P$ concentrations for three rainfall-induced runoff events in 2006 and 2007 and a snowmelt event in 2008 that followed the fall cutting of filter grass. Eight additional runoff events where many plots did not have runoff were excluded from this analysis

\begin{tabular}{|c|c|c|c|c|c|c|c|c|c|c|}
\hline \multirow{2}{*}{$\begin{array}{l}\text { Grass filter area } \\
(\%)\end{array}$} & \multicolumn{2}{|l|}{ Runoff } & \multicolumn{2}{|l|}{ Sediment } & \multicolumn{2}{|l|}{ Total P } & \multicolumn{2}{|c|}{ Dissolved P } & \multicolumn{2}{|c|}{ Particulate P } \\
\hline & $\begin{array}{l}\text { Snow } \\
\text { event } \\
\left(\mathrm{m}^{3} \mathrm{ha}^{-1}\right)\end{array}$ & $\begin{array}{c}\text { Three } \\
\text { events }\end{array}$ & $\begin{array}{l}\text { Snow } \\
\text { event } \\
\left(\mathrm{gL}^{-1}\right)\end{array}$ & $\begin{array}{l}\text { Three } \\
\text { events }\end{array}$ & $\begin{array}{l}\text { Snow } \\
\text { event } \\
\left(\mathrm{mg} \mathrm{L}^{-1}\right)\end{array}$ & $\begin{array}{l}\text { Three } \\
\text { events }\end{array}$ & $\begin{array}{l}\text { Snow } \\
\text { event }\end{array}$ & $\begin{array}{l}\text { Three } \\
\text { events }\end{array}$ & $\begin{array}{l}\text { Snow } \\
\text { event }\end{array}$ & $\begin{array}{l}\text { Three } \\
\text { events }\end{array}$ \\
\hline 0 & 34.6 & $72.4 a^{b}$ & 1.76 & $1.47 \mathrm{a}$ & 2.92 & 2.83 & 2.54 & 1.34 & 0.38 & 1.48 \\
\hline 1.1 & 86.6 & $44.0 \mathrm{a}$ & 2.38 & $1.05 \mathrm{~b}$ & 4.80 & 2.81 & 4.29 & 1.40 & 0.51 & 1.40 \\
\hline 4.3 & 40.0 & $26.2 b$ & 0.89 & $1.11 b$ & 3.89 & 2.82 & 3.24 & 1.48 & 0.65 & 1.42 \\
\hline \multicolumn{11}{|l|}{ Event means } \\
\hline Jul 06 & $26.7 b$ & & $1.10 \mathrm{a}$ & & $3.78 \mathrm{a}$ & & $1.19 \mathrm{~b}$ & & 1.30 & \\
\hline Aug 06 & $38.0 \mathrm{~b}$ & & $0.60 \mathrm{~b}$ & & $3.17 \mathrm{a}$ & & $1.41 b$ & & 1.26 & \\
\hline May 07 & $78.0 \mathrm{a}$ & & $1.20 \mathrm{a}$ & & $1.53 b$ & & $0.79 b$ & & 0.75 & \\
\hline Mar $08^{a}$ & $54.5 \mathrm{ab}$ & & $1.42 \mathrm{a}$ & & $4.00 \mathrm{a}$ & & $3.45 a$ & & 0.53 & \\
\hline
\end{tabular}

No letter means no significant differences among treatments

a. Snowmelt event

b. Means within treatment and event columns with the same letter are not significantly different at $P \leq 0.1$ 
in this section consider separating the analyses of four runoff events (three rainfall and one snowmelt events), where nearly all runoff plots generated runoff to the water tanks. Composite samples were taken to represent all 12 events where missing runoff samples in the tanks were presented. Represented samples were analyzed for sediment and P load and concentration.

\subsection{Three Rainfall and One Snowmelt Runoff Events}

The filter strip treatments did not affect mean $\mathrm{P}$ concentrations for the three rainfall events and one snowmelt-induced runoff event in which most plots had runoff (Table 2). Runoff volume was reduced by 39 and $64 \%$, respectively, with 1.1 and $4.3 \%$ area of grass filters compared with no filter for the rainfall events. Sediment concentration was reduced by $29 \%$ with $1.1 \%$ area of grass filter while $4.3 \%$ area of grass filters for the rainfall events. Runoff volume and concentrations of sediment and $\mathrm{P}$ were not affected by grass filter treatments during the snowmelt event. The results from the rainfall events are in agreement with Magette et al. (1989) who reported that grass filters were less efficient in reducing DRP compared with sediment concentration. The snowmelt event delivered more DRP than rainfall events, possibly because of less infiltration with the snowmelt event attributed to frozen soil as well as lack of vegetative growth. Similar results, that the majority of $\mathrm{P}$ in snowmelt water is dissolved $\mathrm{P}(\mathrm{DP})$ rather than PP, were reported by Jasen et al. (2011). Because of the soil surface underneath, the melting snowpack may become saturated, such that runoff flows through the base of the snowpack toward streams. Infiltration rate and surface storage capacity depend on the soil's physical conditions. In the snowmelt active season, vegetation is rare and the infiltration rate is limited due to the frozen surface soil ( $\mathrm{Li}$ and Simonovic 2002). Another study by Ginting et al. (1998) showed that snowmelt runoff is not as erosive as runoff caused by rain, but loss of water soluble contaminants can be substantial.

\subsection{All Runoff Events}

Grass filters reduced annual runoff volume, based on all 12 runoff events over 2 years, by 54 and $79 \%$, respectively, with 1.1 and $4.3 \%$ grass filter area (Table 3 ). The filter effect on runoff volume was greater with all 12 events considered than for the four selected events considered above because the filter strips prevented runoff in many plots in the other eight events.

Loadings were reduced but concentrations were not significantly reduced with grass filters. The grass filters of 1.1 and $4.3 \%$, respectively, reduced loading by 67 and $84 \%$ for sediment, 73 and $66 \%$ for DRP, and 66 and $82 \%$ for PP (Table 3).

The linear effect of filter width was significant for runoff volume as well as sediment and total and PP loading but runoff volume and loadings were not significantly different for grass filters of $4.3 \%$ compared with $1.1 \%$ of the drainage area. This becomes more meaningful when considering the land area occupied by each grass filters (Figure 5). Grass filters that occupied $1.1 \%$ filter removed $69 \%$ of the sediment, while the additional $3.2 \%$ of plot area occupied by the $4.3 \%$ filter removed an additional $18 \%$ only. There was a slightly greater reduction in sediment load compared with the reduction in runoff volume indicating a net sediment filtering effect. This is consistent with Fox and Sabbagh (2009) who found that a $60 \%$ reduction in flow results in a mean reduction of sediment delivery of $80 \%$.

Under natural conditions, where unbounded runoff plot is presented, it will be a challenge to determine the quantity of runoff. Since the contributing areas of bounded plots are artificially defined, the quantity of runoff, sediment, and P load can be estimate based on the collected runoff and precipitation data. Generally, small field plots are assumed to provide uniform conditions to investigate hydrologic processes by eliminating the heterogeneities arising out of topographical factors, soil, surface cover, and climatic. In this study, the runoff plots have been developed under natural condition, to obtain data involving hydrologic and erosion processes, so, it is hypothesized that the used runoff plot represents local climate, soil, and plant conditions. This runoff plot scale is useful in providing experimental data involving rainfall, surface runoff, and soil erosion, which can be used as reference in modeling conception, calibration, and validation. However, there can be limitations of models attempting to simulate these complexities (Nearing 2004).

Infiltration is expected to be the main mechanism of grass filters for reducing runoff $\mathrm{P}$ as found for filter strips by Dosskey et al. (2007) although Self-Davis et al. (2003) found that filters may be more effective at trapping sediment than reducing runoff. 


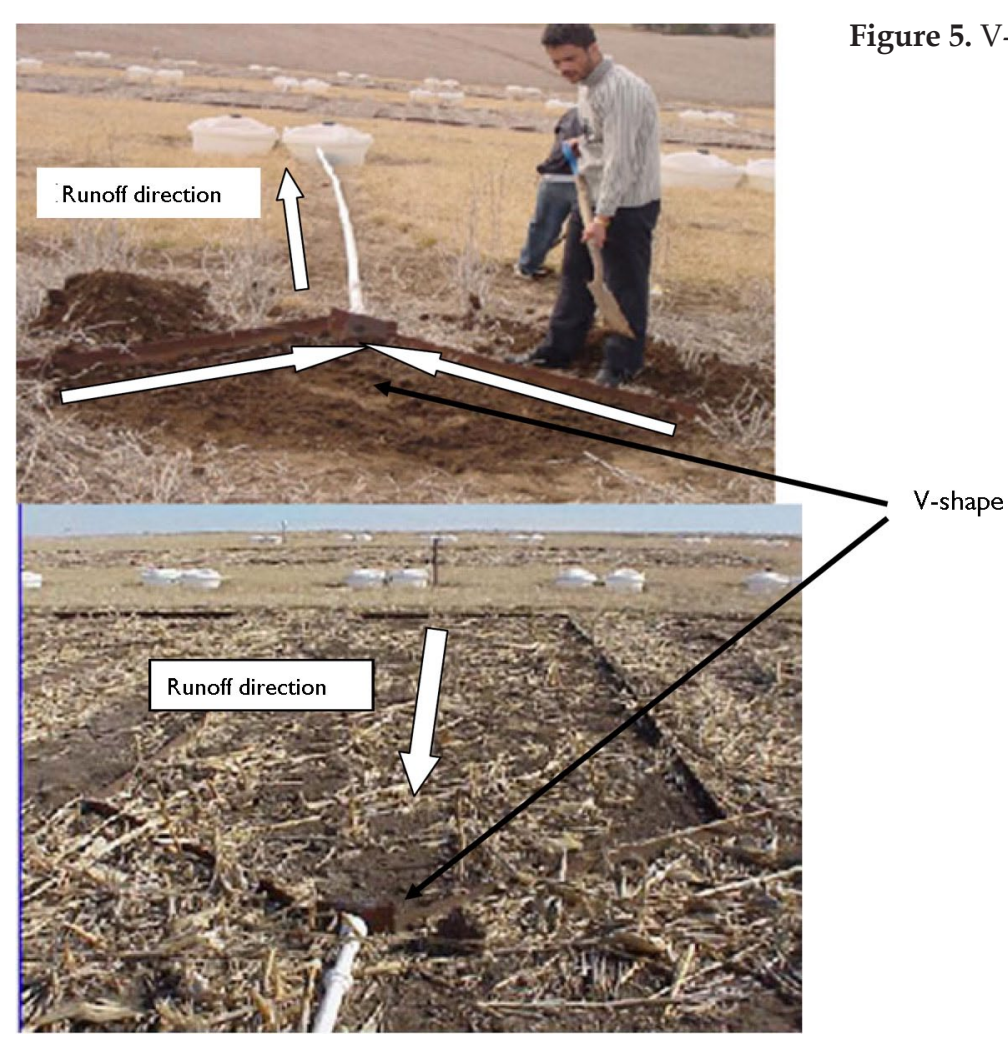

Increased infiltration in the filter area promotes sediment deposition by reducing sediment transport capacity of the remaining runoff (Hayes et al. 1984; and Lee et al. 1989). Saturated hydraulic conductivity and water infiltration rates are important to reducing runoff (Rachman et al. 2004b; Gilley et al. 2000) and soil bulk density is often reduced and macroporosity increased with soil under perennial grass (Rachman et al. 2004a). Filters are expected to be relatively ineffective in cases of slow water infiltration such as with frozen, saturated, or compacted soils or soils of weak aggregation.

Table 3. Effect of grass filter radius on runoff volume as well as on concentration and load of sediment and total, particulate, and dissolved reactive P over 12 runoff events in 2006 and 2007. Four runoff events are where nearly all plots delivered runoff samples. Eight additional runoff events where some plots did not have runoff were included in this analysis

\begin{tabular}{|c|c|c|c|c|c|c|c|c|c|}
\hline \multirow{2}{*}{$\begin{array}{l}\text { Ratio of grass } \\
\text { filter to drainage } \\
\text { area }(\%)\end{array}$} & \multirow{2}{*}{$\begin{array}{c}\text { Runoff } \\
\left(\mathrm{m}^{3} \mathrm{ha}^{-1} \text { year }^{-1}\right)\end{array}$} & \multicolumn{2}{|c|}{ Sediment } & \multicolumn{2}{|c|}{ Total P } & \multicolumn{2}{|c|}{ Dissolved P } & \multicolumn{2}{|c|}{ Particulate $\mathrm{P}$} \\
\hline & & $\overline{\left(\mathrm{gL}^{-1}\right)}$ & $\overline{\left(\mathrm{kgha}^{-1} \text { year }^{-1}\right)}$ & $\overline{\left(\mathrm{mg} \mathrm{L}^{-1}\right.}$ & $\overline{\left.\text { ha }^{-1} \text { year }^{-1}\right)}$ & $\left(\mathrm{mgL}^{-1}\right)$ & $\overline{\left(\text { gha }^{-1} \text { year }^{-1}\right)}$ & $\overline{\left(\mathrm{mg} \mathrm{L}^{-1}\right)}$ & $\overline{\left(\text { gha }^{-1} \text { year }^{-1}\right)}$ \\
\hline $1.1^{\mathrm{a}}$ & $87 b$ & 1.53 & $93 b$ & 2.63 & $151 b$ & 1.25 & $43 b$ & 1.38 & $108 b$ \\
\hline 4.3 & $39 b$ & 1.21 & $47 b$ & 2.82 & $112 b$ & 1.30 & $54 b$ & 1.52 & $58 b$ \\
\hline 2006 & 94 & 1.23 & 85 & 2.46 & $167 \mathrm{~b}$ & 1.21 & $54 \mathrm{~b}$ & 1.25 & $114 b$ \\
\hline 2007 & 118 & 1.46 & 204 & 2.65 & $329 a$ & 1.01 & $121 \mathrm{a}$ & 1.63 & $208 a$ \\
\hline
\end{tabular}

Year $\times$ treatment effects were not significant NS = no significant difference

a. The ratio of grass area to the drainage area $\%$

b. Means within treatment and year columns with the same letter are not significantly different at $P \leq 0.1$

${ }^{*} P \leq 0.05$ (statistically significant difference); ${ }^{*} P \leq 0.01$ (statistically significant difference) 
Modeling sediment and nutrient transport through grass filter barriers is needed to understand and predict pollution transport. While equations have been developed to estimate effectiveness of grass filter for trapping sediments (Tollner et al. 1977; Foster 1982; Flanagan et al. 1989), validation of equations with field and plot data is scarce. A modeling study by Haan et al. (1994) showed that increased slope steepness increases runoff velocity, resulting in decreased sediment deposition by barriers; also, increased slope length and steepness produces higher overland flow velocities and correspondingly higher erosion. Foster (1982) stated that sediment transport through grass strips diminishes exponentially with increasing grass width.

Comparison of grass filter performance during snowmelt and runoff events allows an identification of different flow components and runoff-generating mechanisms. Therefore, the awareness of the dynamic and complex grass filter during two periods is of importance for the development of proper management strategies.

\section{Summary and Conclusion}

This study was conducted to evaluate grass filter area relative to the drainage area for reducing sediment and P loss in runoff. Grass filters trapped sediment and nutrients effectively by increasing infiltration and reducing runoff. Pollutant load was reduced by 54 to $79 \%$ but $P$ concentration was not affected by the filters. Increasing grass filter size to $4.3 \%$ compared with $1.1 \%$ of the drainage area did not significantly reduce sediment and nutrient load. The results demonstrate that much less of the drainage area is needed for well-placed filter areas than commonly used for buffer or filter strips to achieve similar reductions in flow and sediment and nutrient loading. Land area can be efficiently used for surface water protection using grass filters that occupy $1-1.5 \%$ of the drainage area if designed and placed to intercept a spatially uniform flow of runoff. However, filter strips could be less effective for trapping sediment, nitrogen, and phosphorus if flow is not uniform. Dosskey et al. (2002) found that on farms where the concentrated flow was substantial, estimated trapping efficiency was greatly limited; meanwhile, with better flow distribution through existing buffer areas, sediment retention was greatly improved.
Acknowledgments - We are grateful to Dr. David Marx for advice in statistical analysis and to Mr. Mark Strnad for technical assistance in the fieldwork. This research was conducted under the USDA CSREES Managed Ecosystems project 2005-55101-16369.

\section{References}

Abu-Zreig, M., Ruda, R. P., Whiteley, H. R., Lalonde, M. N., \& Kaushik, N. K. (2003). Phosphorus removal in vegetated filter strip. Journal of Environmental Quality, 32, 613-619.

Blanco-Canqui, H., Gantzer, C. J., Anderson, S. H., Alberts, E. E., \& Thompson, A. L. (2004). Grass barrier and vegetative filter strip effectiveness in reducing runoff, sediment, nitrogen, and phosphorus loss. Soil Science Society of America Journal, 68, 1670-1678.

Clausen, J. C., Guillard, K., Sigmund, C. M., \& Dors, K. M. (2000). Water quality changes from riparian buffer restoration in Connecticut. Journal of Environmental Quality, 29, 1751-1761.

Culley, J. L., \& Bolton, E. F. (1983). Suspended solids and phosphorus loads from a clay soil: II. Watershed study. Journal of Environmental Quality, 12, 498-503.

Daniels, R. B., \& Gilliam, J. W. (1996). Sediment and chemical load reduction by grass and riparian filters. Soil Science Society of America Journal, 60, 246-251.

Dillaha, T. A., Sherrard, J. H., \& Lee, D. (1986). Long-term effectiveness and maintenance of vegetative filter strips. Virginia Water Resources Research Center, Virginia Polytechnic Institute and State University, Blacksburg Bulletin 153.

Dillaha, T. A., Reneau, R. B., Mostaghimi, S., \& Lee, D. (1989). Vegetative filter strips for agricultural nonpoint source pollution control. Transactions of ASAE, 32, 513-519.

Dorioz, J. M., Wang, D., Poulenard, J., \& Trévisan, D. (2006). The effect of grass buffer strips on phosphorus dynamics - A critical review and synthesis as a basis for application in agricultural landscapes in France. Agriculture, Ecosystems \& Environment Journal, 117, 4-21.

Dosskey, M. G., Helmers, M. J., Eisenhauer, D. E., Franti, T. G., \& Hoagland, K. D. (2002). Assessment of concentrated flow through riparian buffers. Journal of Soil and Water Conservation, 57, 336-343.

Dosskey, M. G., Hoagland, K. D., \& Brandle, J. R. (2007). Changes in filter strip performance over ten years. Journal of Soil and Water Conservation, 62, 21-32.

Dosskey, M. G., Helmers, M. J., \& Eisenhauer, D. E. (2008). A design aid for determining width of filter strips. Journal of Soil and Water Conservation, 63, 232-241.

Erickson, J. E., Cisar, J. L., Volin, J. C., \& Snyder, G. H. (2001). Comparing nitrogen runoff and leaching between newly established St. Augustine grass turf and an alternative residential landscape. Crop Science, 41, 1889-1895.

Flanagan, D. C., Foster, G. R., Neibling, W. H., \& Burt, J. P. (1989). Simplified equations for filter strip design. Transactions of ASAE, 32, 2001-2007.

Foster, G. R. (1982). Modeling the erosion process. 297-380. In C. T. Haan et al. (Eds.) Hydrologic modeling of small watersheds. ASAE Monographs No. 5. St. Joseph, MI. 
Fox, G. A., \& Sabbagh, G. J. (2009). Comment on 'Major factors influencing the efficacy of vegetated buffers on sediment trapping: A review and analysis', by Liu X, Zhang X, Zhang M in J. Environ. Qual. 2008 37: 1667-1674. Journal of Environmental Quality, 38, 1-3.

Gharabaghi, B., Rudra, R. P., Whiteley, H. R., \& Dickingson, W. T. (2002). p. 289-302. In W. James (Ed.) Development of a management tool for vegetative filter strips. Best modeling practices for urban water systems. CHI Monograph 10, Guelph, Ontario, Canada.

Gilley, J. E., Eghball, B., Kramer, L. A., \& Moorman, T. B. (2000). Narrow grass hedge effects on runoff and soil loss. Journal of Soil and Water Conservation, 55, 190-196.

Ginting, D., Moncrief, J. F., Gupta, S. C., \& Evans, S. D. (1998). Interaction between manure and tillage system on phosphorus uptake and runoff losses. Journal of Environmental Quality, 27, 1403-1410.

Gitau, M. W., Gburek, W. J., \& Jarrett, A. R. (2005). A tool for estimating best management practice effectiveness for phosphorus pollution control. Journal of Soil and Water Conservation, 60, $1-10$.

Gumiere, S. J., Bissonnais, Y. L., Raclot, D., \& Cheviron, B. (2010). Vegetated filter effects on sedimentological connectivity of agricultural catchments in erosion modelling: A review. Earth Surface Processes and Landforms, 36, 3-19.

Haan, C. T., Barfield, B. J., \& Hayes, J. C. (1994). Design hydrology and sedimentology for small catchments (p. 588). San Diego: Academic.

Hayes, J. C., Barfield, B. J., \& Barnhisel, R. I. (1984). Performance of grass filters under laboratory and field conditions. Transactions of ASAE, 27, 1321-1331.

Helmers, M. J., Eisenhauer, D. E., Dosskey, M. G., \& Franti, T. G. (2002). Modeling vegetative filter performance with VFSMOD. ASAE Meeting Paper No. MC02-308.

Helmers, M. J., Isenhart, T. M., Dosskey, M., Dabney, S. M., \& Strock, J. S. (2008). Buffers and vegetative filter strips. USDA Forest Service/UNL Faculty Publications. Paper 20. http:// digitalcommons.unl.edu/usdafsfacpub/20.

Jasen, T., Tiessen, K., Salvano, E., Kalischuk, A., \& Flaten, D. (2011). Spring snowmelt impact on phosphorus addition to surface runoff in the Northern Great Plains. Better Crops, 95:1, 28-31.

Lee, D., Dillaha, T. A., \& Sherrard, J. H. (1989). Modeling phosphorus transport in grass filter strips. Journal of Environmental Engineering, 115, 409-427.

Li, L., \& Simonovic, S. P. (2002). System dynamics model for predicting floods from snowmelt in North American prairie watersheds. Hydrological Processes, 16, 2645-2666.

Liu, X., Zhang, X., \& Zhang, M. (2008). Major factors influencing the efficacy of vegetated buffers on sediment trapping: A review and analysis. Journal of Environmental Quality, 37, 1667-1674.

Magette, W. L., Brinsfield, R. B., Palmer, R. E., \& Wood, J. D. (1989). Nutrient and sediment removal by vegetated filter strips. Transactions of ASAE, 32, 663-667.

Mankin, K. R., Ngandu, M. D., Barden, C. J., Hutchinson, S. L., \& Geyer, W. A. (2007). Grass-shrub riparian buffer removal of sediment, phosphorus, and nitrogen from simulated runoff. Journal of the American Water Resources Association, 43, 1108-1116.

Murphy, J., \& Riley, J. P. (1962). A modified single solution method for the determination of phosphate in natural waters. Analytica Chimica Acta Journal, 27, 31-36.

Nearing, M. A. (2004). Soil erosion and conservation. In Environmental modelling: Finding simplicity in complexity. Chichester: Wiley. ISBN 100-471-49618-9.

Neibling, W. H., \& Alberts, E. E. (1979). Composition and yield of soil particles transported through sod strips. ASAE Paper No. 79-2065. ASAE, St. Joseph, MI.

Nighman, D., \& Harbor, J. (1997). Trap efficiency of a storm water basin with and without baffles. Proceeding International Erosion Control Association, 28, 469-483.

Olsen, S. R., \& Sommers, L. E. (1982). Phosphorus. pp. 403-430. In A. L. Page, R. H. Miller, and D. R. Keeney (Eds.), Methods of soil analysis. 2nd ed. Agronomy Series No. 9, Part 2. Soil Science Society of America Journal, Madison, WI.

Petrovic, A. M. (1990). The fate of nitrogenous fertilizers applied to turfgrass. Journal of Environmental Quality, 19(1), 1-14.

Pote, D. H., \& Daniel, T. C. (2000). Analyzing for dissolved reactive phosphorus in water samples. p. 91-93. In G. M. Pierzynski (Ed.), Methods of phosphorus analysis for soils, sediments, residuals, and waters. Southern Cooperative Series Bull. No. 396. SERA-IEG 17, USDA-CSREES Regional Committee.

Rachman, A., Anderson, S. H., Gantzer, C. J., \& Alberts, E. E. (2004a). Soil hydraulic properties influenced by stiff-stemmed grass hedge systems. Soil Science Society of America Journal, 68, 1386-1393.

Rachman, A., Anderson, S. H., Gantzer, C. J., \& Alberts, E. E. (2004b). Influence of stiff-stemmed grass hedge systems on infiltration. Soil Science Society of America Journal, 68, 2000-2006.

SAS Institute. (2003). The SAS system for Windows. Release 8.2. Cary: SAS Inst.

Schmitt, T. J., Dosskey, M. G., \& Hoagland, K. D. (1999). Filter strip performance and processes for different vegetation, widths, and contaminants. Journal of Environmental Quality, 28, 1479-1489.

Self-Davis, M. L., Moore, P. A., Daniel, T. C., Nichols, D. J., Sauer, T. J., West, C. P., et al. (2003). Forage species and canopy cover effects on runoff from small plots. Journal of Soil and Water Conservation, 58, 349-359.

Tollner, E. W., Barfield, B. J., Vachirakornwatana, C., \& Haan, C. T. (1977). Sediment deposition patterns in simulated grass filters. Transactions of ASAE, 20, 940-944.

USDA-NRCS. (2002) Beef production best management practices (BMPs). Technical report. Pub. 2884. Available at http://hawaii.gov/hdoa/ai/ldc/Beef\%20BMPs\%20LSU\%207-07.pdf . Accessed 13 May 2008.

USEPA (2003). Nonpoint source pollution: The nation's largest water quality problem. USEPA, Office of Water. Available at http:/ /0-www.epa.gov.library.unl.edu/owow/nps/facts/ point1.htm. Accessed 23 April 2008.

Wilson, L. G. (1967). Sediment removal from floodwater by grass filtration. Transactions of ASAE, 10, 35-37. 